\title{
The Influence of the Several Very Large Solar Proton Events in Years 2000-2003 on the Neutral Middle Atmosphere
}

\author{
Charles H. Jackman ${ }^{a}$, Matthew T. Deland ${ }^{b}$, Gordon J. Labow ${ }^{\mathrm{a}, \mathrm{b}}$, Eric L. Fleming, ${ }^{\mathrm{a}, \mathrm{b}}$, Debra K. Weisenstein ${ }^{\mathrm{c}}$, Malcolm \\ K. W. Ko ${ }^{d}$, Miriam Simnhuber ${ }^{e}$, John Anderson ${ }^{\mathrm{f}}$, and James M. Russell ${ }^{\mathrm{f}}$ \\ ${ }^{2}$ Code 916, NASA Goddard Space Flight Center, Greenbelt, MD 20771, USA \\ 'Science Systems and Applications, Inc., 10210 Greenbelt Road, Suite 400, Lanham, MD 20706, USA \\ 'Atmospheric and Environmental Research, Inc., 131 Hartwell Avenue, Lexington, MA 02421, USA \\ 'Mail Stop 401B, NASA Langley Research Center, Hampton, VA 23681, USA \\ 'Institute of Environmental Physics, University of Bremen, Germany, \\ fHampton University, Center for Atmospheric Sciences, Hampton, VA 23668, USA
}

\begin{abstract}
Solar proton events (SPEs) are known to have caused changes in constituents in the Earth's polar neutral middle atmosphere. The past four years, 2000-2003, have been replete with SPEs and huge fluxes of high energy protons occurred in July and November 2000, September and November 2001, and October 2003. The highly energetic protons produce ionizations, excitations, dissociations, and dissociative ionizations of the background constituents, which lead to the production of $\mathrm{HO}_{x}(\mathrm{H}, \mathrm{OH}, \mathrm{HO})$ and $\mathrm{NO}_{\mathrm{y}}\left(\mathrm{N}, \mathrm{NO}, \mathrm{NO}_{2}, \mathrm{NO}_{3}, \mathrm{~N}_{2} \mathrm{O}, \mathrm{HNO}_{3}, \mathrm{HO}_{2} \mathrm{NO}_{2}, \mathrm{ClONO}_{2}\right.$, $\mathrm{BrONO}_{2}$ ). The $\mathrm{HO}_{x}$ increases lead to short-lived ozone decreases in the polar mesosphere and upper stratosphere due to the short lifetimes of the $\mathrm{HO}_{x}$ constituents. Large mesospheric ozone depletions ( $\left.>70 \%\right)$ due to the $\mathrm{HO}_{x}$ enhancements were observed and modeled as a result of the very large July 2000 SPE. The $\mathrm{NO}_{\mathrm{y}}$ increases lead to long-lived stratospheric ozone changes because of the long lifetime of the $\mathrm{NO}_{y}$ family in this region. Polar total ozone depletions $>1 \%$ were simulated in both hemispheres for extended periods of time (several months) as a result of the $\mathrm{NO}_{y}$ enhancements due to the very large SPES.
\end{abstract}

\section{Introduction}

Explosions on the Sun sometimes result in large fluxes of high-energy solar protons at the Earth, especially near Solar Maximum. This period of time, wherein the solar proton flux is generally elevated for a few days, is known as a solar proton event (SPE). Solar cycle 23 experienced a large number of extremely energetic SPEs in years 2000-2003. Huge fluxes of high-energy protons occurred in July and Novernber 2000, September and November 2001, and October 2003.

Solar protons are guided by the Earth's magnetic field and impact both the northern and southern polar cap regions ( $>60^{\circ}$ geomagnetic latitude), e.g., see Jackman and McPeters (2004). These protons can impact the neutral middle atmosphere (stratosphere and mesosphere) and produce ionizations, dissociative ionizations, and excitations. Both $\mathrm{HO}_{\mathrm{x}}\left(\mathrm{H}, \mathrm{OH}, \mathrm{HO}_{2}\right)$ and $\mathrm{NO}_{y}\left(\mathrm{~N}, \mathrm{NO}, \mathrm{NO}_{2}, \mathrm{NO}_{3}, \mathrm{~N}_{2} \mathrm{O}_{5}, \mathrm{HNO}_{3}, \mathrm{HO}_{2} \mathrm{NO}_{2}, \mathrm{ClONO}_{2}, \mathrm{BrONO}_{2}\right.$ ) constituents are produced either directly or through a photochemical sequence (e.g., Swider and Keneshea, 1973; Crutzen et al. 1975; Jackman et al. 1980; Solomon et al. 1981; McPeters 1986; Zadorozhny et al. 1992). Ozone is also impacted by the solar protons through direct photochemical destruction forced by the $\mathrm{HO}_{\mathrm{x}}$ and $\mathrm{NO}_{\mathrm{y}}$ enhancements (e.g., Weeks et al. 1972; Heath et al. 1977; Solomon et al. 1983; Jackman et al. 1990).

The SPEs that occurrat in years 2000-2003 were noteworthy and details of their atmospheric response, including both satellite measurements and model predictions are included in this discussion. The paper is divided into six primary sections, including the introduction. We discuss the very important solar proton measurements and their production of odd hydrogen $\left(\mathrm{HO}_{\mathrm{x}}\right)$ and odd nitrogen $\left(\mathrm{NO}_{\mathrm{y}}\right)$ in section 2 . A comparison of the SPEs in solar cycle 23 with some of the largest in past solar cycles is also undertaken in section 2 . The GSFC two-dimensional model used to simulate the impact of the SPES on the atmosphere is discussed in section 3 . The short-term impact of 
these SPEs on ozone during and for several days after particular events is given in section 4. Longer term influences of the SPEs on the middle atmosphere are discussed in section 5. Finally, the conclusions are given in section 6.

\section{Proton Fluxes; Odd Hydrogen $\left(\mathrm{HO}_{\mathbf{x}}\right.$ ) and Odd Nitrogen $\left(\mathrm{NO}_{\mathbf{y}}\right)$ Production}

Solar proton fluxes are measured by a few satellites in interplanetary space or in orbit around the Earth. The most accessible and useful proton flux data are available from the National Oceanic and Atmospheric Administration (NOAA) Space Environment Center (SEC) for the NOAA Geostationary Operational Environmental Satellites (GOES) [see http://sec.noaa.gov/Data/goes.html]. GOES proton fluxes are provided in several energy intervals ( $>1$ $\mathrm{MeV},>5 \mathrm{MeV},>10 \mathrm{MeV},>30 \mathrm{MeV},>50 \mathrm{MeV}$, and $>100 \mathrm{MeV}$ ) at this site, updated every five minutes. GOES-8 data are considered most reliable for proton fluxes depositing energy into polar latitudes (private communication, Terry Onsager, NOAA SEC). GOES-8 data are, therefore, used for the periods January 1, 2000 to April 8, 2003; and May 10, 2003 to June 18, 2003. GOES-11 became the primary satellite for protons on June 19, 2003 and was used as the proton flux source through December 31, 2003. GOES-10 data was used to fill in the gap of missing proton flux data from April 9 to May 9, 2003.

The solar proton fluxes were used to compute daily average ion pair production profiles using the energy deposition methodology discussed in Vitt and Jackman (1996). Odd hydrogen $\left(\mathrm{HO}_{\mathrm{x}}\right.$ ) is formed through complicated ion chemistry (Solomon et al. 1981). Each ion pair is assumed to produce two $\mathrm{HO}_{\mathrm{x}}$ constituents up to an attitude of approximately $70 \mathrm{~km}$. Above $70 \mathrm{~km}$, the $\mathrm{HO}_{\mathrm{x}}$ production is assumed to be that provided by Solomon et al. (1981, Figure 2). The $\mathrm{HO}_{\mathrm{x}}$ constituents have lifetimes of only hours in the middle atmosphere, therefore, any further effects on other constituents from the $\mathrm{HO}_{\mathrm{x}}$ group are apparent only during and shortly after an SPE.

Atomic nitrogen is produced by the primary protons and associated secondary electrons causing dissociations, predissociations, or dissociative ionizations in collisions with $\mathrm{N}_{2}$. Following Porter et al. (1976) and Jackman et al. (1980), we assume that $1.25 \mathrm{~N}$ atoms are produced per ion pair. The $\mathrm{N}$ atoms rapidly produce NO and other odd nitrogen $\left(\mathrm{NO}_{\mathrm{y}}\right.$ ) constituents. Odd nitrogen has a relatively short lifetime (-days) in the sunlit midde and upper mesosphere, however, lower mesospheric and stratospheric $\mathrm{NO}_{\mathrm{y}}$ can last for weeks past an SPE. A mostly dark middle atmosphere in the late fall and winter conserves a large portion of the SPE-produced $\mathrm{NO}_{\mathrm{y}}$, which can then be transported to lower altitudes via the general downward flowing winds during this time of year. The lifetme of this enhanced $\mathrm{NO}_{\mathrm{y}}$ can range from months to years if transported to the middle and lower stratosphere.

We have quantified middle atmospheric $\mathrm{NO}_{y}$ production before (Jackman et al. 1980, 1990; Vitt and

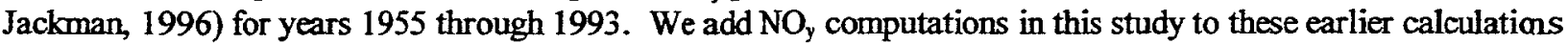
for years 1994 through 2003 and present the annual production from SPEs for the 49-year period 1955 through 2003 in Figure 1. The source of proton flux data for years 2000 through 2003 was explained above. For the years 1994 through 1999 we use two satellites: 1) GOES-7 for the period January 1, 1994 through February 28, 1995; and 2) GOES-8 for the period March 1, 1995 through the end of 1999. The annual-averaged sunspot number is also shown in Figure 1 to illustrate the rough correlation between solar maximum periods and frequency of SPEs.

Solar cycle 23 was quite active with several very large SPEs (also, see Krivolutsky et al. 2003), especialy in years 2000 (July and November), 2001 (September and two in November), and 2003 (October). Substantial amounts of $\mathrm{NO}_{\mathrm{y}}$ were produced in 2000,2001, and 2003 with 1989 being the only year showing a larger production. The ten largest SPEs in the past 40 years are given in Table 1 with six of them occurring in the past solar maximm period.

\section{GSFC Two-Dimensional Model}

The latest version of the Goddard Space Flight Center (GSFC) two-dimensional (2D) atmospheric model was used to predict atmospheric changes caused by the solar protons. The model has been in use since the late 1980 's and has undergone extensive improvements over the years (Douglass et al. 1989; Jackman et al. 1990). Fleming et al. (2002) describes the methodology to compute the transport for the GSFC 2D model. This techniqe uses the global winds and temperatures from the United Kingdom Meteorological Office (UKMO) data assimilatin system for the years 1992-2000. The photochemical reaction rates have been recently updated to Sander et al. (2003). The GSFC 2D chemistry solver has been improved and now uses the Atmospheric Environmental Reseach 
(AER) 2D model scheme (Ko et al. 1984). The new chemistry solver allows a diurnal cycle simulation every day and provides for a more accurate simulation of atmospheric constituents.

\section{Short-term Atmospheric Influences from Solar Proton Events}

We used the GSFC 2D model to compute two primary simulations, the "base" and the "perturbed" simulations, for the years 1998 through 2005 . The transport for years 1998-2000 is driven by the UKMO products for those particular years, whereas the transport for the individual years 2001-2005 is a repeat of that derived for 2000. The "base" simulation includes no SPEs, whereas the "perturbed" simulation includes all SPEs from January 1,2000 through December 31,2003 . The perturbation to the atmosphere was caused by the SPE-produced $\mathrm{HO}_{x}$ and $\mathrm{NO}_{y}$ enhancement.

We show the $\mathrm{HO}_{x}$ production (in $\# \mathrm{~cm}^{-1} \mathrm{~s}^{-1}$ ), ozone depletion (in percent), and $\mathrm{NO}_{x}\left(\mathrm{NO}+\mathrm{NO}_{2}\right.$ ) enhancement (in ppbv) in Figure 2 as a result of the extremely large solar proton event that started on Bastille Day (July 14) in 2000. The model computations are compared with Upper Atmosphere Research Satellite (UARS) HALogen Occulation Experiment (HALOE) ozone and $\mathrm{NO}_{x}$ measurements. The HALOE observed constituent changes during July 14-18 were calculated by comparing to the background atmospheric amounts before the SPE, defined as the average of the July 12-13 measurements. The produced $\mathrm{HO}_{\mathrm{x}}$ constituents drive practically all the ozone depletion in the mesosphere and the upper stratosphere during the event. There are several $\mathrm{HO}_{\mathrm{x}}$ catalytic destruction cycles for ozone. An example of one that is important in the middle and upper mesosphere is:

$$
\text { Net: } \begin{array}{r}
\mathrm{H}+\mathrm{O}_{3} \rightarrow \mathrm{OH}+\mathrm{O}_{2} \\
\mathrm{OH}+\mathrm{O} \rightarrow \mathrm{H}+\mathrm{O}_{2}
\end{array}
$$

The $\mathrm{NO}_{\mathrm{x}}$ enhancement can cause some of the depletion in the upper stratosphere and lower mesosphere during the event, but forces all of the ozone depletion after July 16 (Figure $2 c, 2 d$, and $2 \mathrm{e}$ ). Ozone is reduced by the $\mathrm{NO}_{\mathbf{x}}$ constituents through the following primary catalytic destruction cycle:

$$
\text { Net: } \begin{array}{r}
\mathrm{NO}+\mathrm{O}_{3} \rightarrow \mathrm{NO}_{2}+\mathrm{O}_{2} \\
\mathrm{NO}_{2}+\mathrm{O} \rightarrow \mathrm{NO}+\mathrm{O}_{2} \\
\hline \mathrm{O}_{3}+\mathrm{O} \rightarrow \mathrm{O}_{2}+\mathrm{O}_{2} .
\end{array}
$$

The ozone changes are similar between HALOE measurements and model computations during the maximum intensity of the July 14-16, 2000 SPE. Both measurements and model calculations show a maximum of about $70 \%$ depletion in the middle and upper mesosphere on July 15 . The model computed ozone depletions in the lower mesosphere and upper stratosphere are larger than that measured by HALOE on July 16 (late in the day) and on July 17-18 (see Figure $2 \mathrm{~b}$ and $2 \mathrm{c}$ ). The ozone reduction by SPE-enhanced $\mathrm{HO}_{\mathrm{x}}$ is thus fairly reasonably simulated, whereas the ozone reduction by SPE-enhanced $\mathrm{NO}_{\mathrm{x}}$ appears to have difficulties. It is possible that the HALOE measured ozone change is underestimated due to some long-term secular change that may occur over a few days.

Clearly, the HALOE and modeled $\mathrm{NO}_{\mathrm{x}}$ are enhanced in the mesosphere and upper stratosphere on July 17-18 (Figure $2 \mathrm{~d}$ and $2 \mathrm{e}$ ) by the extremely large SPE. These $\mathrm{NO}_{\mathrm{x}}$ enhancements should lead to a reduced ozone, which is simulated by the model in Figure $2 \mathrm{c}$. The computed enhanced $\mathrm{NO}_{\mathrm{x}}$ is somewhat larger than measured in the middle and upper mesosphere on July 17-18, but is similar to the observed $\mathrm{NO}_{\mathrm{x}}$ in the lower mesosphere and upper stratosphere during these two days. 


\section{Long-term Atmospheric Influences from Solar Proton Events}

Over the course of a few days, the enhancements of $\mathrm{NO}$ and $\mathrm{NO}_{2}$ from SPEs elevate the amount of other $\mathrm{NO}_{\mathrm{y}}$ constituents. As noted above, the $\mathrm{NO}_{\mathrm{y}}$ family has a lifetime of months to years if transported to the middle and lower stratosphere. Transport to lower altitudes is especially effective in the middle to late Fall and Winter, when the middle atmospheric winds are directed polewards and downwards.

Four very large SPEs occurred in the northern middle to late Fall time period (see November 2000, November 2001, and October 2003 in Table 1). The SPE-related $\mathrm{NO}_{\mathrm{y}}$ enhancements were thus produced at an opportune time to be conserved for a very long period of time. We computed the percentage change of $\mathrm{NO}_{\mathrm{y}}$ and ozone in the northern polar latitudes $\left(50-90^{\circ} \mathrm{N}\right)$ for years 2000-2005 and present the results in Figure $3 . \mathrm{NO}_{\mathrm{y}}$ enhancements of greater than $100 \%$ are noted on several occasions in the upper stratosphere and lower mesosphere, however, the SPE-caused $\mathrm{NO}_{\mathrm{y}}$ increases in the middle to late Fall periods lead to much larger and longer-lasting middle and lower stratospheric enhancements. Much of the northern polar middle stratosphere has computed $\mathrm{NO}_{\mathrm{y}}$ enhancements of $>10 \%$ in 2001, 2002, and 2004 as a result of the middle to late Fall very large SPEs. These periods are highlighted in gray in Figure 3 (upper plot). The increased NOy led to a northern polar stratospheric ozone depletion for extended periods. SPE-caused depletions in ozone greater than $2 \%$ are highlighted in gray in Figure 3 (lower plot) to show the scope of this effect.

The impact on total ozone is shown in Figure 4 . Total ozone is reduced by a maximum of about $3 \%$ in late 2001 and 2002. Much of this depletion was caused by the huge amount of $\mathrm{NO}_{y}$ produced by the July $2000 \mathrm{SPE}$ in the Winter, which was conserved and transported downwards (Randall et al. 2001), where it steadily reduced ozone over a period of a few months. This July 2000 SPE-enhanced stratospheric $\mathrm{NO}_{\mathrm{y}}$ was slowly reduced over time, however, other large SPEs also added to the $\mathrm{NO}_{\mathrm{y}}$ reservoir in both the southern and northern hemispheres. Both polar hemispheres had extended periods of depleted ozone greater than $1 \%$ (highlighted in gray) as a result of SPEs.

\section{Conclusions}

Six very large SPEs occurred in solar cycle 23 and caused very significant perturbations in the polar middle atmospheric regions. These SPE-caused influences were quite substantial (e.g., $>70 \%$ ozone destruction), but also very short-lived ( days) in the middle and upper mesosphere. The SPE-produced $\mathrm{HO}_{\mathrm{x}}$ likely caused the ozone depletions in this atmospheric region. The $\mathrm{NO}_{\mathrm{y}}$ enhancements from the SPEs caused some ozone depletion on a short-time scale (days) during the events in the lower mesosphere and upper stratosphere. However, much of the $\mathrm{NO}_{\mathrm{y}}$ lasted for a longer time period of months past the very large SPEs. A longer-lived ozone destruction was connected to this SPE-enhanced $N_{y}$. Depletions greater than $1 \%$ were computed for both northern and southern polar hemispheres.

\section{Acknowledgements}

We thank the NOAA GOES team for providing the solar proton flux data over the internet.

\section{References}

Crutzen, P. J., I. S. A. Isaksen, and G. C. Reid, Solar proton events: Stratospheric sources of nitric oxide, Science, $189,457-4581975$.

Douglass, A. R., C. H. Jackman, and R. S. Stolarski, Comparison of model results transporting the odd nitrogen family with results transporting separate odd nitrogen species, J., Geophys. Res., 94, 9862-9872, 1989.

Fleming, E. L., C. H. Jackman, J. E. Rosenfield, and D. B. Considine, Two-dimensional model simulations of the QBO in ozone and tracers in the tropical stratosphere, J. Geophys. Res., 107(D23), 4665, doi:10.1029/2001JD001146, 2002.

Heath, D. F., A. J. Krueger, and P. J. Crutzen, Solar proton event: influence on stratospheric ozone, Science, 197, 886-889, 1977. 
Jackman, C. H., J. E. Frederick, and R. S. Stolarski, Production of odd nitrogen in the stratosphere and mesosphere: An intercomparison of source strengths, J. Geophys. Res., 85, 7495-7505, 1980.

Jackman, C. H., A. R. Douglass, R. B. Rood, R. D. McPeters, and P. E. Meade, Effect of solar proton events on the middle atmosphere during the past two solar cycles as computed using a two-dimensional model, $J$. Geophys. Res., 95, 7417-7428, 1990.

Jackman, C. H., R. D. McPeters, G. J. Labow, E. L. Fleming, C. J. Praderas, and J. M. Russell, Northern hemisphere atmospheric effects due to the July 2000 solar proton event, Geophys. Res. Lett., 28, 2883-2886, 2001.

Ko, M. K. W., N. D. Sze, M. Livshits, M. B. McElroy, and J. A. Pyle, The seasonal and latitudinal behavior of trace gases and $\mathrm{O} 3$ as simulated by a two-dimensional model of the atmosphere, J. Atmos. Sci., 41, 2381-2408, 1984.

Krivolutsky, A., A. Kuminov, T. Vyushkova, N. Pereyaslova, and M. Nazarova, Proton activity of the Sun during $23^{\text {rd }}$ solar maximum and its response in ozonosphere of the Earth, Adv. Space Res., 31, 2151-2156, 2003.

McPeters, R. D., A nitric oxide increase observed following the July 1982 solar proton event, Geophys. Res. Lett., $13,667-670,1986$.

Porter, H. S., C. H. Jackman, and A. E. S. Green, Efficiencies for production of atomic nitrogen and oxygen by relativistic proton impact in air, J. Chem. Phys., 65, 154-167, 1976.

Randall, C. E., D. E. Siskind, and R. M. Bevilacqua, Stratospheric $\mathrm{NO}_{\mathrm{x}}$ enhancements in the southern hemisphere polar vortex in winter and spring of 2000, Geophys. Res. Lett, 28, 2385-2388, 2001.

Sander, S. P., et al., Chemical kinetics and photochemical data for use in atmospheric studies, JPL Publication 02$25,2003$.

Solomon, S., D. W. Rusch, J.-C. Gerard, G. C. Reid, and P. J. Crutzen, The effect of particle precipitation events on the neutral and ion chemistry of the middle atmosphere, 2, Odd hydrogen, Planet. Space Sci., 29, 885-892, 1981.

Solomon, S., G. C. Reid, D. W. Rusch, and R. J. Thomas, Mesospheric ozone depletion during the solar proton event of July 13, 1982, 2, Comparison between theory and measurements, Geophys. Res. Lett., 10, 257-260, 1983.

Swider, W., and T. J. Keneshea, Decrease of ozone and atomic oxygen in the lower mesosphere during a PCA event, Planet. Space Sci., 21, 1969-1973, 1973.

Vitt, F. M., and C. H. Jackman, A comparison of sources of odd nitrogen production from 1974 through 1993 in the Earth's middle atmosphere as calculated using a two-dimensional model, $J$. Geophys. Res., 101, 6729-6739, 1996.

Weeks, L. H., R. S. CuiKay, and J. R. Corbin, Ozone measurements in the mesosphere during the solar proton event of 2 November 1969, J. Atmos. Sci., 29, 1138-1142, 1972.

Zadorozhny, A. M., G. A. Tuchkov, V. N. Kikhtenko, J. Lastovicka, J. Boska, and A. Novak, Nitric oxide and lower ionosphere quantities during solar particle events of October 1989 after rocket and ground-based measurements, J. Atmos. Terr. Phys., 54, 183-192, 1992.

Table 1. Largest ten solar proton events in past forty years

\begin{tabular}{|c|c|c|}
\hline Date of SPEs & $\begin{array}{c}\text { Rank in } \\
\text { size }\end{array}$ & $\begin{array}{c}\text { NO production } \\
\text { in the middle atmosphere } \\
\text { (\# of molecules) }\end{array}$ \\
\hline October 19-27, 1989 & 1 & $6.7 \times 10^{33}$ \\
August 2-10,1972 & 2 & $3.6 \times 10^{33}$ \\
July 14-16, 2000 & 3 & $3.5 \times 10^{33^{*}}$ \\
October 28-31,2003 & 4 & $3.4 \times 10^{33}$ \\
November 5-7, 2001 & 5 & $3.2 \times 10^{33}$ \\
November 9-11,2000 & 6 & $2.3 \times 10^{33}$ \\
September 24-30,2001 & 7 & $2.0 \times 10^{33}$ \\
August 13-26, 1989 & 8 & $1.8 \times 10^{33}$ \\
November 23-25, 2001 & 9 & $1.7 \times 10^{33}$ \\
September 2-7, 1966 & 10 & $1.2 \times 10^{33}$ \\
& \\
\hline
\end{tabular}



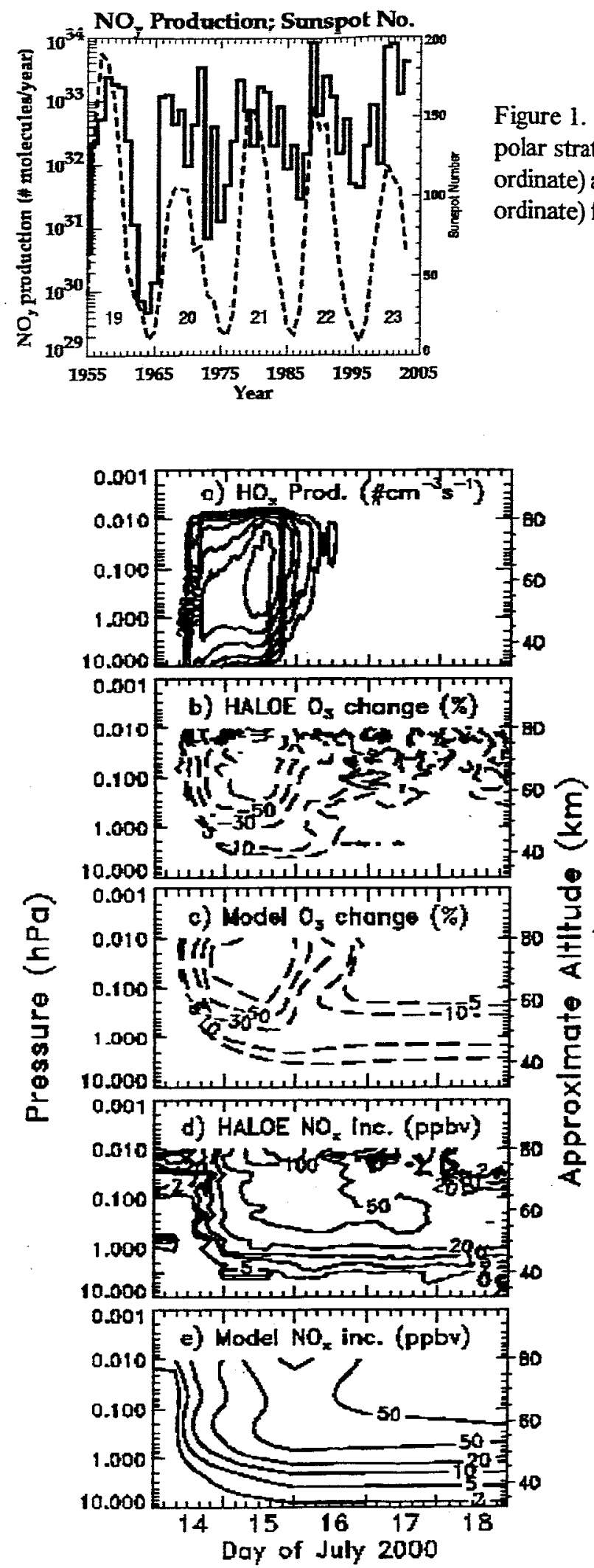

Figure 1. Total number of $\mathrm{NO}_{\mathrm{y}}$ molecules produced per year in the polar stratosphere and mesosphere by SPEs (solid histogram - left ordinate) and annually-averaged sunspot number (dashed line - right ordinate) for years 1955 through 2003.
Figure 2. Polar Northern Hemisphere (near $65^{\circ} \mathrm{N}$ ) pressure versus time cross sections during the perturbed period (July 14-18, 2000) for a) $\mathrm{HO}_{\mathrm{x}}$ production for contour levels $200,500,1000,2000,5000,10000$, and $20000 \mathrm{~cm}^{-3} \mathrm{~s}^{-1}$; b) HALOE $\mathrm{O}_{3}$ and c) model $\mathrm{O}_{3}$ decreases, both for contour levels $-5,-10,-30,-50$, and $-70 \%$; d) HALOE $\mathrm{NO}_{\mathrm{x}}$ and e) model $\mathrm{NO}_{\mathrm{x}}$ increases, both for contour levels $2,5,10,20,50,100$, and $200 \mathrm{ppbv}$. The HALOE ozone and $\mathrm{NO}_{x}$ changes were computed by comparing to the background average of the July 12-13 observations. The model changes were computed by comparing the "perturbed" to the "base" simulation. 

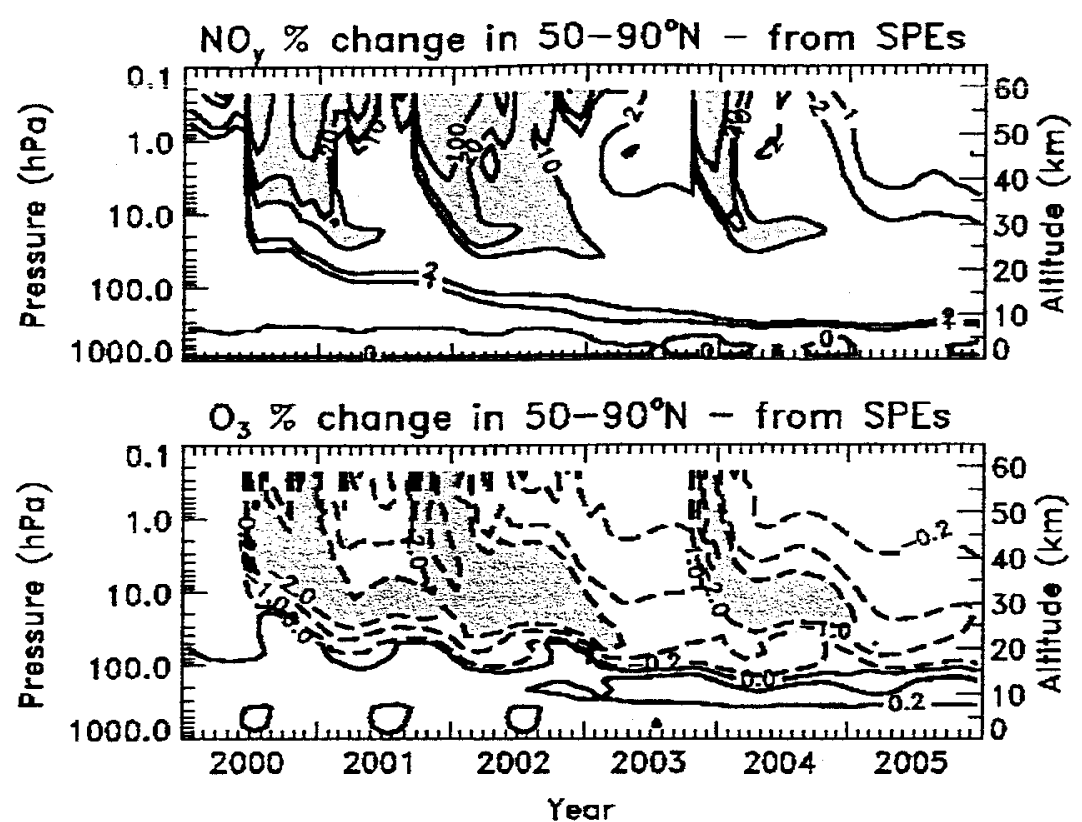

Figure 3. Model computed percentage changes in $\mathrm{NO}_{\mathrm{y}}$ and $\mathrm{O}_{3}$ for the polar Northern Hemisphere area $\left(50-90^{\circ} \mathrm{N}\right)$ for $2000-2005$ resulting from SPEs in 2000-2003. Contour levels for $\mathrm{NO}_{y}$ (top plot) are $0,+1,+2,+10,+20$, and $+100 \%$. The gray highlighted areas for $\mathrm{NO}_{\mathrm{y}}$ indicate increases greater than $10 \%$. Contour levels for $\mathrm{O}_{3}$ (bottom plot) are $-20,-10,-2,-1$, $-0.2,0,+0.2 \%$. The gray highlighted areas for $\mathrm{O}_{3}$ indicate decreases greater than $2 \%$. These changes were computed by comparing the "perturbed" to the "base" simulation.

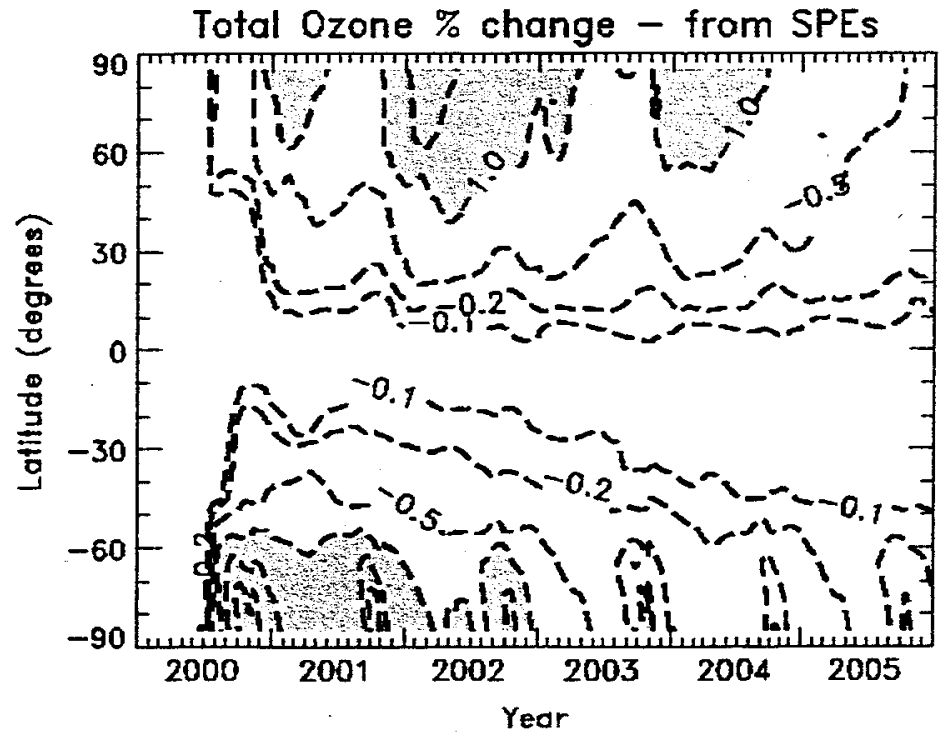

E-mail address of C. H. Jackman - Charles.H.Jackman@nasa.gov Manuscript received 15 July, 2004
Figure 4. Model computed percentage total ozone changes from 2000-2005 resulting from SPEs in 2000-2003. Contour intervals are $-3,-2,-1,-0.5,-$ 0.2 , and $-0.1 \%$. The gray highlighted areas indicate total ozone decreases greater than $1 \%$. These changes were computed by comparing the "perturbed" to the "base" simulation. 


\title{
The Influence of the Several Very Large Solar Proton Events in Years 2000-2003 on the Neutral Middle Atmosphere
}

\author{
Charles H. Jackman, Matthew T. Deland, Gordon J. Labow, Eric L. Fleming, \\ Debra K. Weisenstein, Malcolm K. W. Ko, Miriam Sinnhuber, \\ John Anderson, and James M. Russell
}

\section{Brief, Popular Summary of the Paper:}

Several very large solar proton events occurred in the past solar cycle during years 20002003. These events caused changes in polar mesospheric and stratospheric ozone and other constituents. The influence of these natural processes on ozone need to be more fully understood so that the human-made impact on ozone can be more reliably predicted.

Large-scale explosions on the Sun near solar maximum lead to emissions of charged particles (mainly protons and electrons) from the Sun. Occasionally the Earth is positioned in its orbit such that these solar particles interact with the Earth's magnetosphere and rain down on the polar regions. "Solar proton events" have been used to describe these phenomena since the protons associated with these solar events cause the most atmospheric disturbance.

Solar proton events create hydrogen- and nitrogen-containing compounds, which can lead to ozone destruction in the mesosphere and upper stratosphere. Six of the largest ten events in the past 40 years occurred in the years 2000-2003. The solar protons connected with the July 2000 event caused short-lived ( 1-2 days) mesospheric ozone decreases of over $70 \%$ because of the increases in the hydrogen-containing constituents. Increases in the longer-lived nitrogen oxides caused several extended periods ( months) of polar total ozone depletions of greater than $1 \%$. 